\title{
Advancing Energy Performance in Oil and Gas Industry through Systematic Implementation of Energy Efficiency Programs by Applying an Operational Excellence Model
}

\author{
Hashim K. M¹, Ng D. K. S ${ }^{2}$, Mimi H. Hassim ${ }^{1 *}$ \\ ${ }^{1}$ School of Chemical and Energy Engineering, Faculty of Engineering, Universiti Teknologi Malaysia, \\ 81310 Johor Bahru, Johor, Malaysia \\ ${ }^{2}$ Department of Chemical \& Environmental Engineering, University of Nottingham, 43500 Semenyih, \\ Selangor, Malaysia \\ *Corresponding author: mimi@cheme.utm.my
}

\section{Article History}

Received: March 15, 2018 Received in revised form: Nov 9, 2018 Accepted: Nov 12, 2018 Published: Nov 30, 2018

\begin{abstract}
Energy performance has becoming one of the top global discussion subjects due to the facts of hiked in fossil fuel price, changed in living standards, increased in Green House Gas (GHG) awareness as well as fair business practices such as subsidies and environment regulations. It has pushed societal expectations on oil companies' especially National Oil Companies (NOCs) located in Middle East to rigorously conserve energy and explore ways to enhance its performance. In current industrial practice, Energy Efficiency Programs (EEP) is one of typical initiatives that have been evolving since the late 1990s. However, its progress has just been seen and unfortunately, NOCs are far away from a matured management in addressing EEP expectations. Most of NOCs consider EEP as an ambition, rather than a condition applying to all levels of the businesses. In fact, cost reduction is a main focus rather than to execute right energy conservation strategies and more seriously, lack of a dedicated focus to efficiently use energy resources. This paper presents a methodology that can induce rapid deployment and implementation of a customized EEP. The methodology requires to embed the EEP into the Operation Excellence Model (OEM), a well structured organization' management framework model as defined by European Foundation of Quality Management (EFQM). Since OEM is company-wide initiative, therefore it can be a perfect vehicle to drive EEP in reaching maturity. Through a successful case study, this methodology has proven to drastically improve the implementation pace of EEP and drive tremendous reduction in energy consumption as well as GHG emissions.
\end{abstract}

Keywords: Energy performance; energy management systems; energy efficiency programs; energy performance; operational excellence

\subsection{INTRODUCTION}

Oil and gas industry will remain essential to global economic and prosperity for decade to come [1]. In fact, World Bank indicates that fossil fuel is still a major source of the world power generation as the demand will grow at the average of $3.6 \%$ to $4.0 \%$ per annum toward year 2035 [2]. The era of easy oil is almost gone; therefore, oil and gas companies are under tremendous pressure to increase their oil reserves especially from risky unconventional fields which definitely will consume more energy over barrel of oil produced. Particularly to NOCs that are accounted for more than half of fossil fuel production. NOCs are facing a tough challenge as some restrictions are expected to be imposed by World Trade Organization (WTO) on the energy efficiency and subsidy as measures to reduce GHG generation as well as to promote fair competition respectively [3]. Peoples are more demanding for clean environment such as outcomes from Conference of the Parties (COP) 21 for their commitment to reduce GHG emissions [4]. All of these are affecting their business continuity as net production is declined as same as profits margin [5]. 
Implementing an appropriate EEP can be a major contribution to address those challenges [6]. The EEP consists of customized steps to address specific expectations and requirements of concerned NOCs [1]. Main references of EEP are Energy Management Systems (EnMS) as published by International Organization for Standardization [7] and other relevant best practices. Despite of the increased in energy demand and societal expectations for effectiveness of EEP implementation, it appears that progress has just started and companies are far away from a matured management in addressing real energy efficiency issues [8]. Most of companies consider EEP as a slogan without deep involvement from all concerned entities. In addition, financial impact from energy efficiency is always been given a top priority and lack of a dedicated support to drive for improvement in energy performance [9].

As reference to Middle East region where most of major NOCs are located, but it is considered the least efficient (Arab Forum, 2013). Most of companies in this region including NOCs are still lack of strong push to establish a comprehensive EEP framework and strategies in implementing successful EEP. Without comprehensive EEP framework, it makes implementation failure inevitable [8]. Similarly, lack of strong implementation strategies, will jeopardize the intention of EEP [10]. In addition, firm commitments from various levels within any concerned NOC, establishing right strategies, planning, executing agreed action items, monitoring and revising strategies as necessary have yet to be realized. Summary of obstacles that will be limiting effectiveness of EEP implementation is illustrated in the Figure 1.

According to Arab Forum, strong push is required through common management platform such as Total Quality Management (TQM), Operational Excellence Model (OEM) and Reliability Centered Management (RCM). Those are common corporate-level management programs that are implemented to optimize the efficiency and reliability of a company [11].

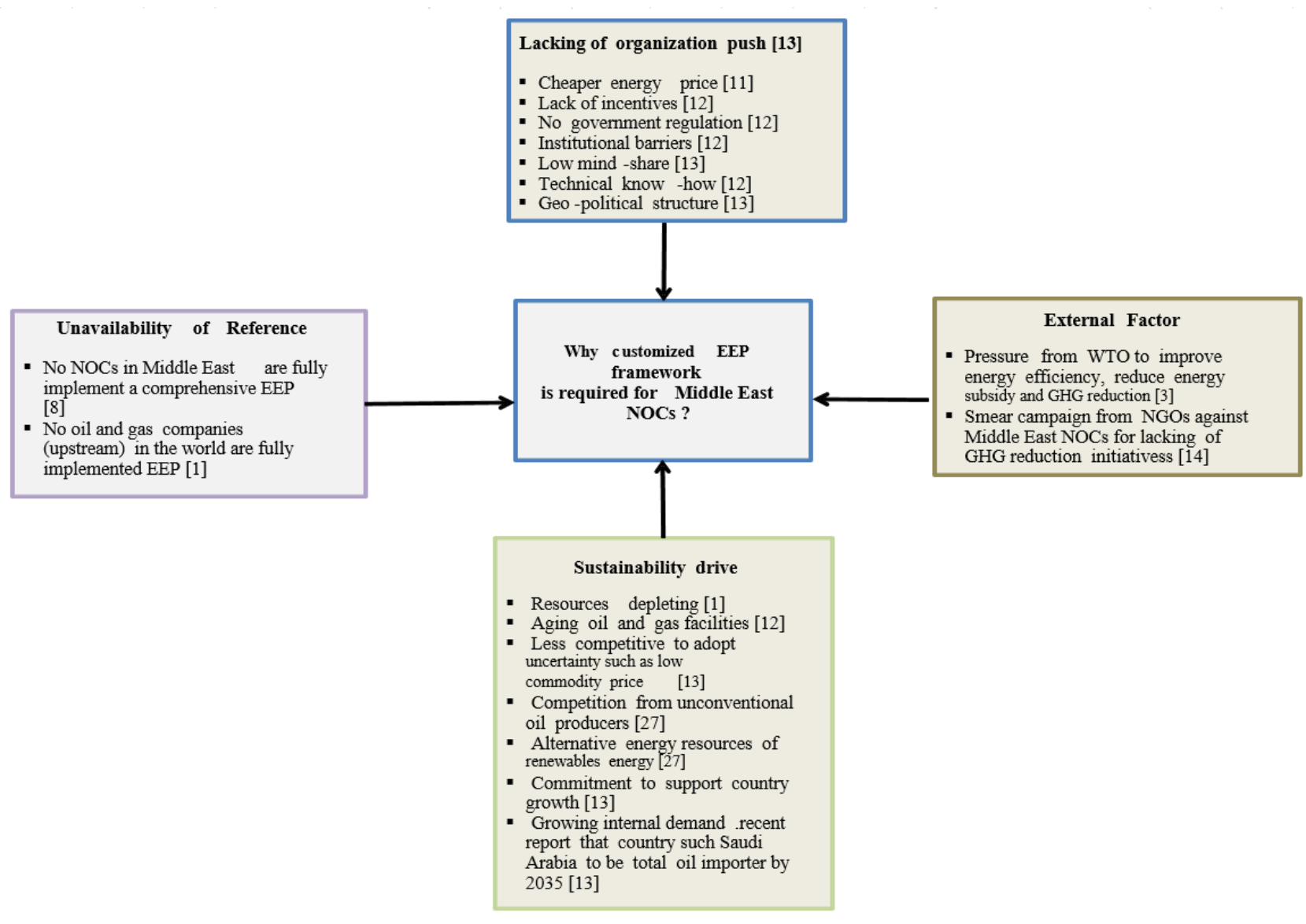

Figure 1. Obstacles for implementing EEP

The objective of this paper is to describe step by step actions based on a proven methodology to ease deployment and implementation of the EEP. This methodology is proven to assist drastic improvement in EEP implementation pace at one of leading NOCs. Therefore, it shall be an important reference to all concerned NOCs. Although a significant amount of works have been done to conclude the said methodology, it will only be effective with the two main conditions; all concerned NOCs have been implementing EEP and OEM even at smaller scales. 


\subsection{METHODOLOGY}

In the Figure 2 provides brief methodology of this whole study as presented in this paper. Industries best-practices, lessons learned and some other supported documents were referred in defining the most effective steps for enhancing EEP implementation. It followed by conducting two surveys to understand challenges and expectations from customers. Therefore, an effective implementation methodology shall be applied in order to enhance implementation pace of the EEP. A case study for the successful implementation of the said methodology at one of NOC' facility shall be included in the paper.

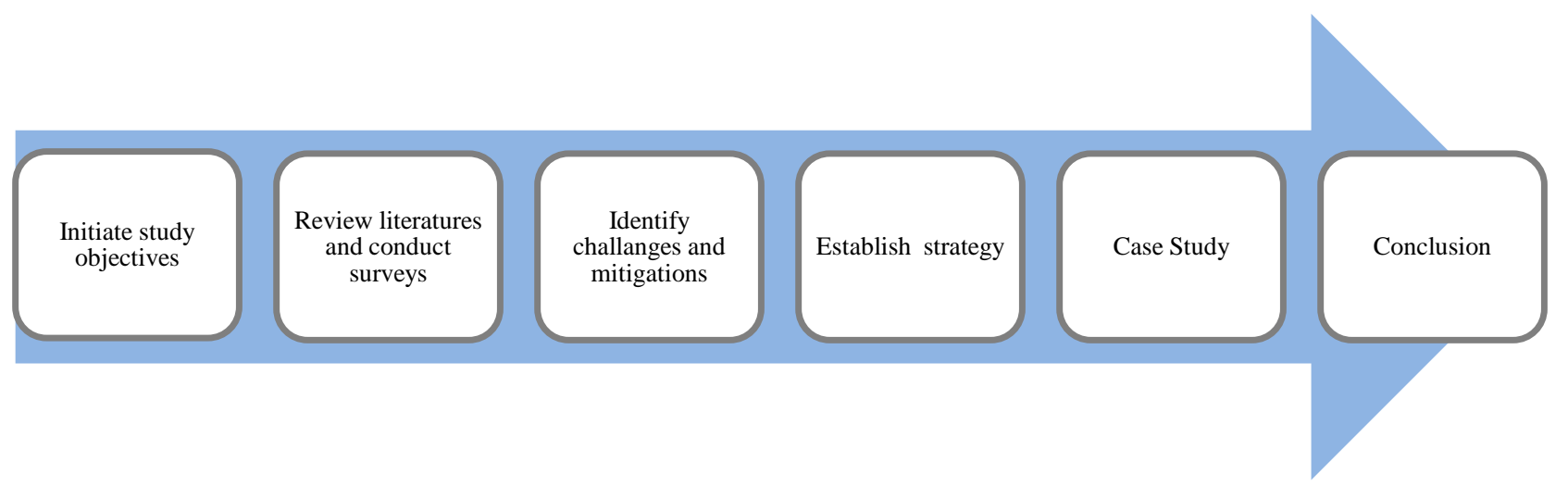

Figure 2. Methodology steps

\subsection{RESULTS AND DISCUSSION}

\subsection{Implementation strategy}

Two surveys were conducted on thirty anonymous facilities from one of leading NOCs to understand challenges in implementing EEP and to identify common mitigations approach to address all those challenges. The findings of common challenges and mitigations in implementing the EEP are listed in Table 1. The customized EEP shall be implemented by applying the recommended mitigations from the Table 1. The Figure 3 illustrates proposed execution stages and their activity descriptions are as follows;

- $\quad$ Establish EEP guidelines based on reputable standards such as ISO50001, United State of America (USA) superior energy program [14] or even companies' customized guidelines based on its experiences in energy conservation activities.

- Identify organization applicability to EEP. This is an important task to ensure the EEP application is not overwhelmed.

- Customize EEP framework based on company business activities and its experiences in energy conservation.

- $\quad$ Embed EEP into existing management program such as OEM, TQM, RCM or any other matured programs deployed by the companies.

- Simplify the EEP steps by means of no repetition with other matured programs.

- Follow driving platform activities such as execution of energy plans, management review meeting, documentation, custodian or governance.

- Continuous improvement efforts such as conducting internal and external assessment, knowledge transfer, training, awareness as well as benchmarking its process and performance. 
Table 1. List of typical' EEP Implementation challenges and proposed Mitigation

\begin{tabular}{|c|c|c|}
\hline $\begin{array}{l}\text { Challenges (based on } \\
\text { Survey } 1 \text { and 2) }\end{array}$ & $\begin{array}{c}\text { Mitigations } \\
\text { (based on Survey 2) }\end{array}$ & Identified Implementation strategy \\
\hline $\begin{array}{l}\text { Set clear corporate } \\
\text { direction }\end{array}$ & $\begin{array}{l}\text { - Establish comprehensive EEP policy } \\
\text { - Identify clear links between energy policies to relevant } \\
\text { focus areas } \\
\text { - Strengthen governance of EEP } \\
\text { - Define Energy performance indicators (EnPIs) and } \\
\text { conduct regular monitoring campaign } \\
\text { - Develop EEP with the main objective to improve energy } \\
\text { performance } \\
\text { - Embed EEP into existing companywide programs such as } \\
\text { OEM } \\
\text { - Establish relevant standards, policies and best practices } \\
\text { - Check applicability of the EEP }\end{array}$ & $\begin{array}{l}\text { - Follow energy policy checklist and indicate clear } \\
\text { link to respective focus areas } \\
\text { - Gather commitment from management through } \\
\text { regular performance update } \\
\text { - Gain momentum with other matured programs such } \\
\text { as OEM, TQM or RCM. } \\
\text { - Adopt the right EEP which provide; } \\
\text { - Simplicity to users } \\
\text { - Consistence with other management programs } \\
\text { such as EMS, SMS and others } \\
\text {-Establish applicability checklist }\end{array}$ \\
\hline $\begin{array}{l}\text { Gain commitments } \\
\text { from; } \\
\text { a. Top management. } \\
\text { b. Energy coordinator } \\
\text { c. All critical positions } \\
\text { d. Employees and } \\
\quad \text { contractors }\end{array}$ & $\begin{array}{l}\text { a. Establish customized EEP courses for management } \\
\text { b. Describe detailed roles and responsibilities in respective } \\
\text { guidelines } \\
\text { c. Conduct companywide awareness session, rewards and } \\
\text { basic energy conservation practices } \\
\text { d. Establish customized awareness program }\end{array}$ & $\begin{array}{l}\text { - Introduce short course to senior and middle } \\
\text { management } \\
\text { - Combine EEP with other matured programs such as } \\
\text { OEM, TQM and TPM. } \\
\text { - Include roles and responsibilities of management, } \\
\text { energy coordinator and energy team in EEP } \\
\text { framework } \\
\text { - Adopt a simplified EEP } \\
\text { - Provide relevant awareness events such as e- } \\
\text { learning courses and journals }\end{array}$ \\
\hline $\begin{array}{l}\text { Solve conflicting } \\
\text { priority }\end{array}$ & Define scope of work for respective energy practitioners & $\begin{array}{l}\text { - Endorse EEP' champion position } \\
\text { - Appointment letters } \\
\text { - Include in individual performance goal }\end{array}$ \\
\hline Enhance competency & $\begin{array}{l}\text { - } \begin{array}{l}\text { Provide relevant trainings } \\
\text { Engage adequate resources such as budget allocation and } \\
\text { others }\end{array} \\
\end{array}$ & $\begin{array}{l}\text { - Develop list of recommended courses } \\
\text { - Include detailed qualification of critical EEP } \\
\text { positions in the framework }\end{array}$ \\
\hline $\begin{array}{l}\text { Analyse energy data and } \\
\text { conduct corrective and } \\
\text { preventive action }\end{array}$ & $\begin{array}{l}\text { - Identify significant energy users (SEUs) } \\
\text { - Ensure SEUs performances are tracked } \\
\text { - Conduct internal audit } \\
\end{array}$ & $\begin{array}{l}\text { - Establish data collection mechanism. } \\
\text { - Simplify operating manuals. } \\
\text { - Specify requirement for EEP internal assessment }\end{array}$ \\
\hline $\begin{array}{l}\text { High cost of } \\
\text { implementing EEP }\end{array}$ & Simplify development and implementation program & Embed into existing companywide programs \\
\hline $\begin{array}{l}\text { Obtain full } \\
\text { Implementation }\end{array}$ & $\begin{array}{l}\text { - Conduct internal EEP assessment } \\
\text { - Emphasize energy efficiency as a factor in facility design } \\
\text { and operation } \\
\text { - Encourage continuous energy conservation by } \\
\text { employees } \\
\text { - Reward and recognition program } \\
\text { - Status update and corporate audit } \\
\end{array}$ & $\begin{array}{l}\text { - Introduce self-evaluation assessment } \\
\text { - Establish comprehensive EEP. } \\
\text { - Conduct awareness needs analysis } \\
\text { - Establish communication plan. } \\
\text { - Human Resource appreciation program } \\
\text { - Combine with other companywide existing program } \\
\text { such as OEM, TQM and TPM }\end{array}$ \\
\hline $\begin{array}{l}\text { Increase pressure from } \\
\text { society such as new } \\
\text { product and legal } \\
\text { requirements }\end{array}$ & $\begin{array}{l}\text { - Improve EEP coverage and implementation } \\
\text { - Benchmark EEP with internal and external organizations } \\
\text { on EEP steps }\end{array}$ & $\begin{array}{l}\text { - Adopt right EEP } \\
\text { - Define clear benchmarking mechanism to capture } \\
\text { best-practices }\end{array}$ \\
\hline $\begin{array}{l}\text { Be best in class } \\
\text { organization }\end{array}$ & $\begin{array}{l}\text { - Gain international recognition on EEP } \\
\text { - Conduct competitive benchmarking with external } \\
\text { organization on energy performance } \\
\text { - Improve energy practitioners' competency }\end{array}$ & $\begin{array}{l}\text { - Engage reputable third party assessors such as } \\
\text { ISO50001 certification } \\
\text { - Define clear benchmarking mechanism } \\
\text { - Identify all required trainings }\end{array}$ \\
\hline
\end{tabular}

\section{Establish EEP guidelines}

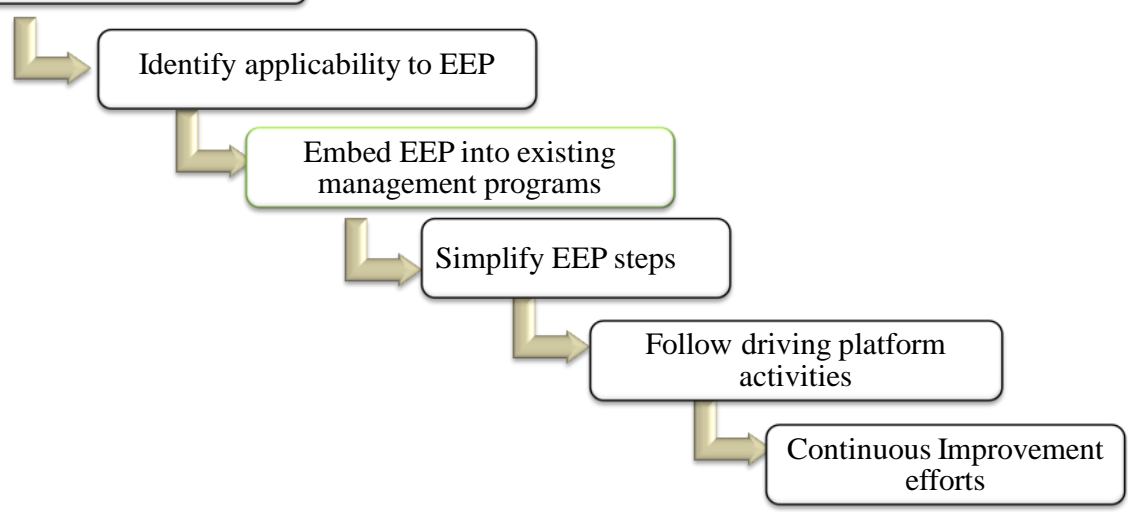

Figure 3. Execution stages 
Achieving the desired outcomes of EEP is challenging that requires highest level of planning, commitments and a strong push by company-wide platforms such as OEM which recently is one the most popular and preferred management models amongst those successful companies (Refer to Table 2 for typical management programs platforms).

Table 2. Typical management programs platforms

\begin{tabular}{|c|l|l|}
\hline Program & \multicolumn{1}{|c|}{ Scope } & \multicolumn{1}{|c|}{ Remark } \\
\hline TQM & $\begin{array}{l}\text { TQM is a structured approach to organizational management that } \\
\text { seeks for quality improvement of products and services through } \\
\text { continuous refining from customer feedback. [15]. }\end{array}$ & $\begin{array}{l}\text { TQM is difficult to be fully deployed and implemented } \\
\text { company-wide. TQM focuses mainly in product and quality } \\
{[16] .}\end{array}$ \\
\hline RCM & $\begin{array}{l}\text { Maintenance strategy to be implemented prior to optimize the } \\
\text { maintenance program on each concerned operating organization } \\
\text { [15]. }\end{array}$ & $\begin{array}{l}\text { This is a plant maintenance program; to improve reliability } \\
\text { of equipment and production units [17]. }\end{array}$ \\
\hline TPM & $\begin{array}{l}\text { It is an approach placed by enforcing the responsibility for routine } \\
\text { maintenance on the operators who operate the machinery, rather } \\
\text { than employing separate maintenance crew for that function [18]. }\end{array}$ & $\begin{array}{l}\text { TPM is application of preventive maintenance strategies in } \\
\text { anganized and standardized method. It does not provide } \\
\text { coverage for the whole organization activities [15]. }\end{array}$ \\
\hline LSS (Lean & $\begin{array}{l}\text { This is a fact-based, data-driven philosophy of improvement that } \\
\text { values defect prevention over defect detection. It drives customer } \\
\text { satisfaction and bottom-line results by reducing variation, waste, } \\
\text { and cycle time, while promoting the use of work standardization } \\
\text { and flow [18]. }\end{array}$ & $\begin{array}{l}\text { LSS is tool to enhance product quality. LSS does not cover } \\
\text { the entire management processes [20]. }\end{array}$ \\
\hline OEM & $\begin{array}{l}\text { Programs for problem-solving, teamwork, and leadership results } \\
\text { in the ongoing improvement in an organization. It involves } \\
\text { focusing on the customers' needs, keeping the employees positive } \\
\text { and empowered, and continually improving the current activities } \\
\text { in the workplace [19]. }\end{array}$ & $\begin{array}{l}\text { OEM provides coverage for entire management platforms. } \\
\text { [21] and [22]. }\end{array}$ \\
\hline
\end{tabular}

Many hidden benefits and potential losses can be discovered by this OEM concept [21]. The OEM is an integrated management system that drives business productivity by applying proven practices and procedures to address organization main performance focus areas. Therefore, deployment under OEM' platform as a driving vehicle is a smart way to promote least matured and unpopular programs such as EEP application within the company. OEM mandates simplification of EEP in several aspects such as internal or external assessment collaboration with other matured programs such as Environmental Management Systems (EMS), Safety Management Systems (SMS), Enterprise Risk Management (ERM) and Total Plant Reliability Management (TPRM).

\subsection{Customized Energy Efficiency Programs (EEP)}

In order to be consistence with OEM execution scope, the customized EEP has to incorporate some of the OEM expectations from EFQM [19] and [23]. Expectations such as human resource, asset management, root cause analysis and benchmark are inserted as new steps into an existing EEP which mainly consists of requirements of international standard [17], Energy Star from United States' Environment Protection Agency [24] as well as common best practices from other management systems. By clearly linking all related steps to defined focus area such as environment and cost efficiency, it will provide a clear picture and therefore promote criticality of EEP to the highest level at par with other matured programs such as safety, environment as well as plant reliability management programs. Figure 4 provides link between expectations, EEP' steps and therefore focus area.

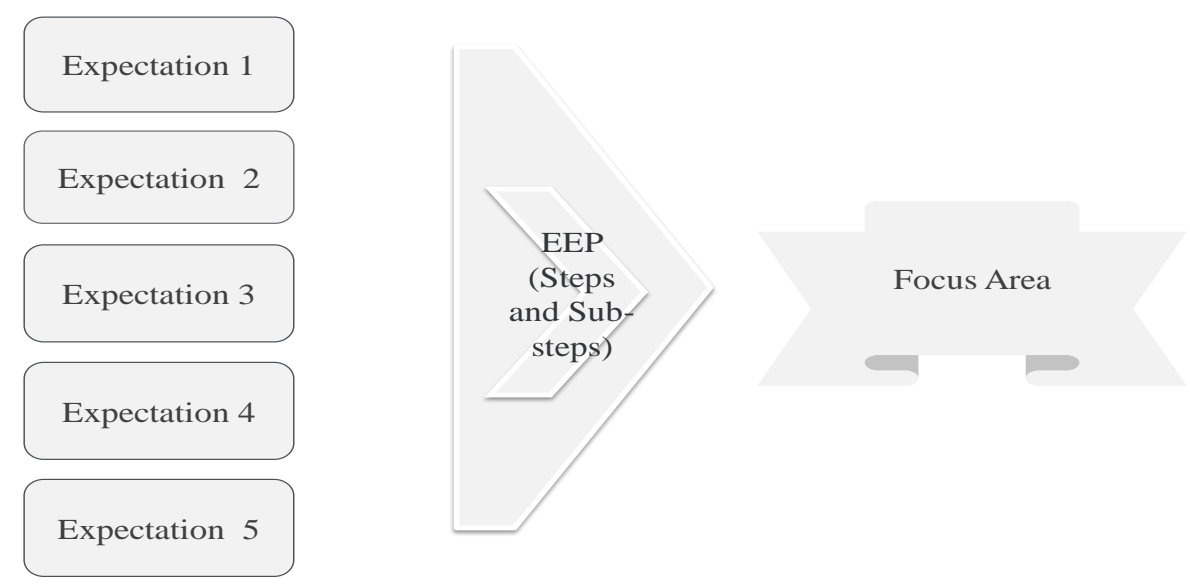

Figure 4. Linking between expectations, enabler and applicable focus areas 
As referred to similar flow of Figure 4, it starts by addressing all given expectations (requirements) of EnMS [7], OEM and other common best-practices to enable for customizing the EEP. DuPont Company identifies that EEP underlying the key enabling element of process management together with other processes that support and drive the attainment of those performance objectives or focus areas [25]. Focus areas that are commonly applied by industries; efficiency for cost reduction from energy savings, environment for reduction of GHG emission or reliability for meeting customers' requirements. Typical EEP' steps in accordance to Deming' Plan-Do-Check-Act (PDCA) cycle is illustrated in a Figure 5 [16]. Brief description of EEP related PDCA are as follows;

Plan : Establish policy, assign function and responsibilities as well as define energy plans.

Do : Raise awareness, improve competency, identify energy savings opportunities as well as to efficiently operate SEUs.

Check : Collect and monitor energy performance data.

Act : Conduct management review, recognize achievement and gather feedback to enhance energy performance.

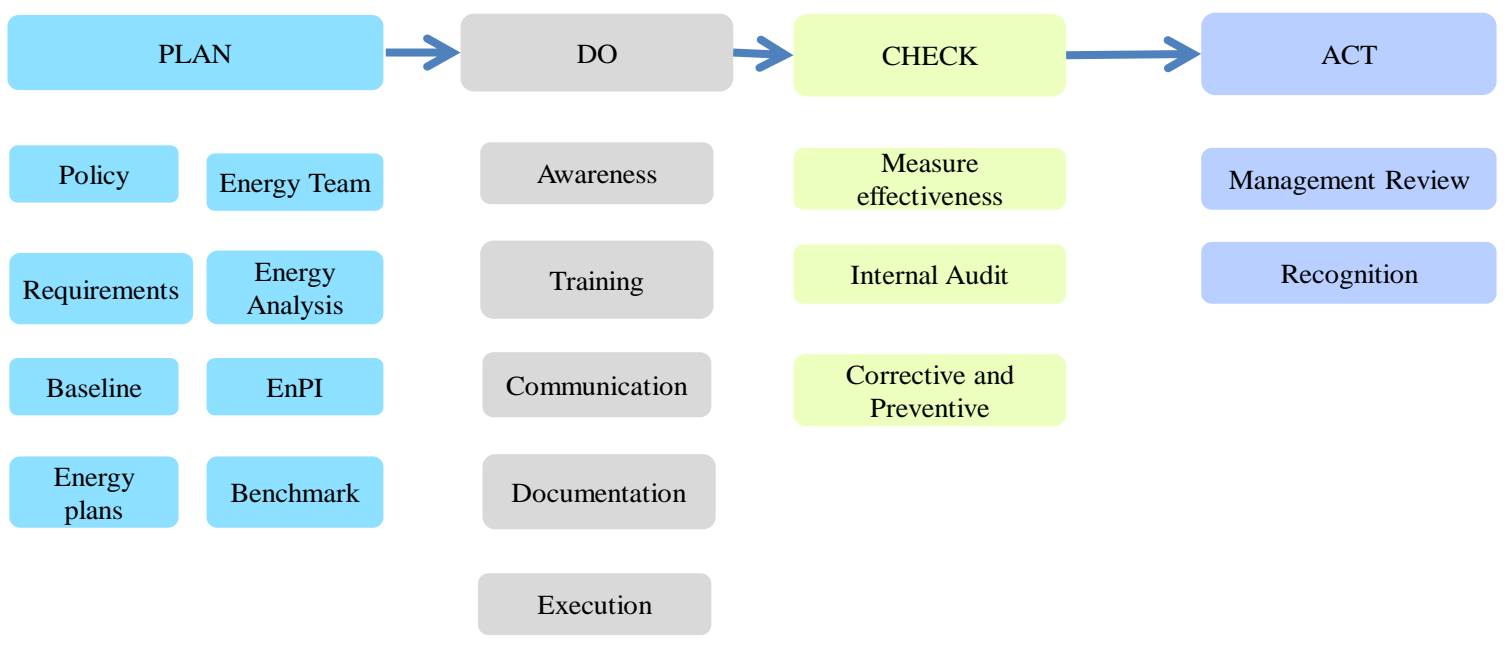

Figure 5. Energy EEP Steps steps and sub-steps

\subsection{Benefits of implementing EEP through Operational Excellence Model (OEM)}

Implementing of EEP under the umbrella of OEM is a proven methodology to induce overall success at many companies such as Chevron [26] and DuPont [25]. These companies realize the benefits that enhance their performance such as gaining competitive advantage in improving their business performance and becoming successful visionary organizations. Adopting systematic EEP will benefit the NOCs by means of;

- Standardization and enhancement of major work processes across the company functions.

- $\quad$ Reduce time spend during development, implementation, performance monitoring and governing the EEP.

- Capture and dissemination of tacit knowledge retained by a few subject matter experts.

- Clarification of accountabilities and responsibilities to each function.

- $\quad$ Proactive identification of problems and opportunities for improvement.

- Enhancement of asset integrity and reliability techniques and processes.

- Engage full attention to all required focus area, enablers, expectations and processes.

- Optimize resources through consolidate compliance assessment on respective enablers, expectations and processes

\subsection{Case study}

In a case study, one of leading NOCs in Middle East has successfully implemented the EEP based on this methodology. Referred as the Company, it has initiated the EEP at corporate level since year 2005, even before the establishment of internationally recognized ISO50001:2011 for EnMS standard. Over fifty applicable facilities under the Company have been mandated to embrace each element of its established EEP guidelines with the intent to become more energy efficient, energy responsible and to demonstrate this responsibility to the Company stakeholders, government and/or public. Each of applicable facility shall establish a customized EEP to provide comprehensive energy performance measure in order 
to drive for successful deployment of EEP.

The Company values the EEP as a continuous improvement tool that enhances productivity and cost gains, as well as sustaining a challenging growth rate. In parallel, the Company aims to sustain its leading performance towards becoming a reliable and cost effective global energy supplier. Therefore, it is the responsibility of each facility to perform the followings:

- Embrace the Company' customized EEP guidelines with the objective to continually improve energy performance and meeting expectations of the programs.

- Gain commitment from all levels within the facility in conserving energy.

- Deploy energy efficiency initiatives as earliest as possible during the facility design stages as well as in operations.

- Monitor its implementation status.

During initial stage of EEP implementations, it was quite disappointed due to delays, lack of commitment or even rejection. These responsibilities sound complicated and caused slow pace in implementation, together with other obstacles such as lack of support from top management, resources constraint and geo-political structure. Mitigation of these challenges requires a strong push from top management of the Company. The Company has introduced the OEM in 2013 to strengthen its business portfolio and the EEP has been concluded as one of the Company' critical programs. Deployment of EEP as part of OEM is an effective methodology to make EEP at par with other matured programs. Part of implementation methodology is to customize EPP by incorporating selected expectations from OEM. In addition, adoption of EEP into OEM will mitigate almost all obstacles as previously accounted.

The methodology has drastically improved implementation pace of EEP. As indicated in Figure 6, within less than three years since it was initiated, the progress of company-wide EEP implementations has boosted up to $89 \%$ towards meeting the minimum requirement of ISO50001. Several of the Company' facilities referred as A, B, C, D, E and F achieved full marks on their EEP self-assessment. The Figure 7 illustrates implementation progress of its facilities on each elements of Plan-Do-Check-Act to meeting minimum requirement of ISO50001 [7]. The systematic approach from well proven methodology has resulted in a significant energy savings that exceeds tens of thousands barrel oil per day of oil equivalent and tremendous reduction of GHG emissions.

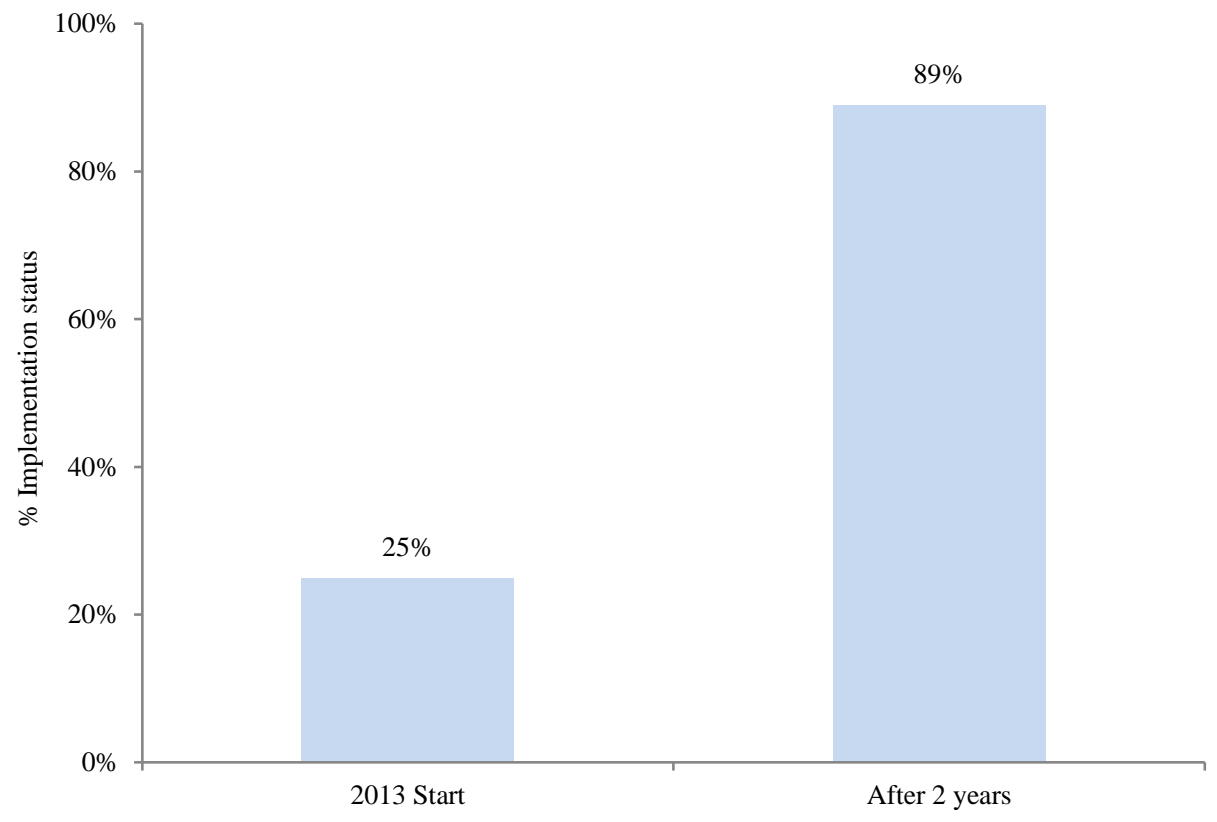

Figure 6. Company EEP Implementation Status 


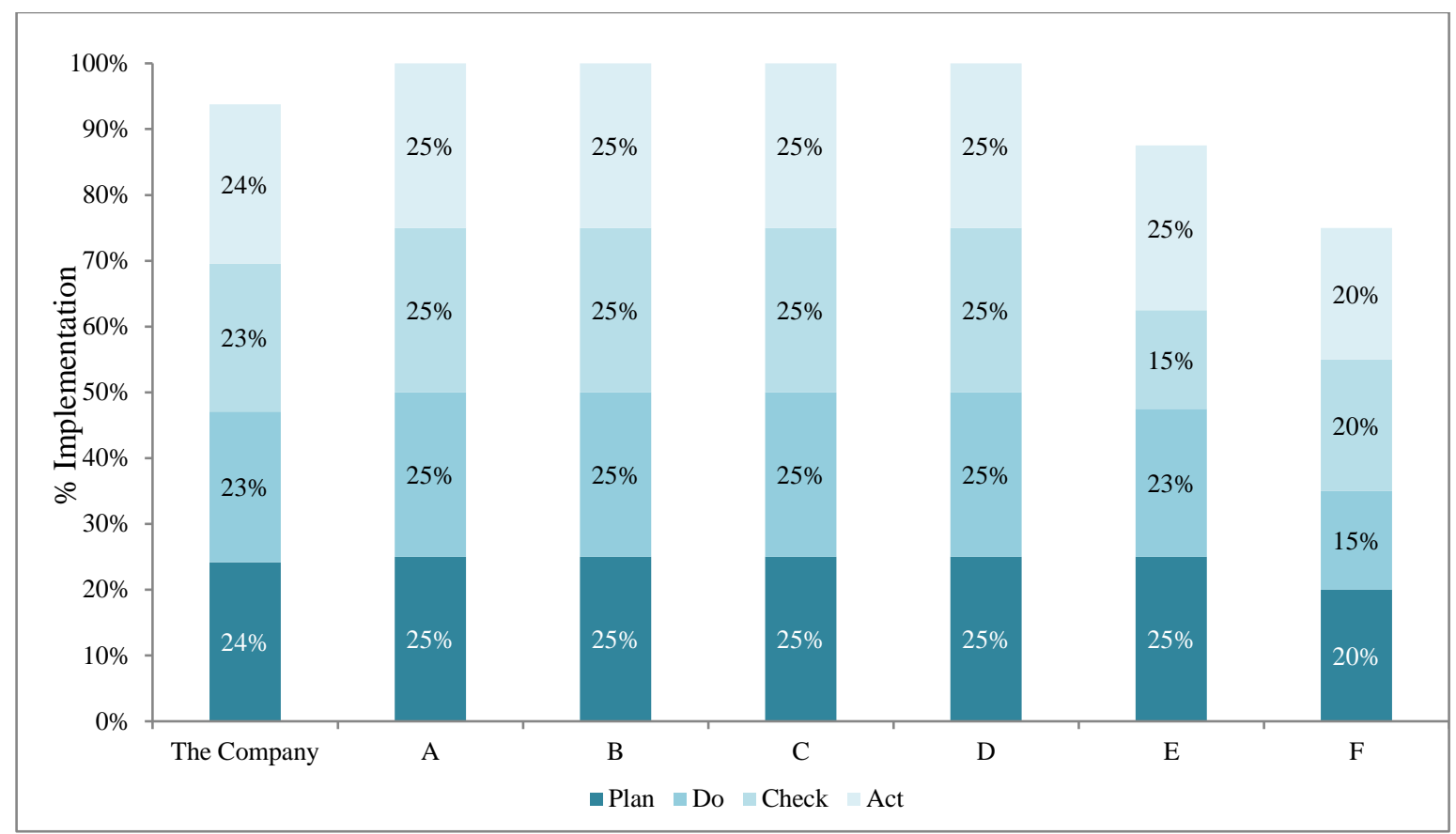

Figure 7. EEP implementation status for The Company' facilities (A, B, C, D, E and F) (after 2 years)

\subsection{CONCLUSION}

A successful EEP implementation requires systematic methodology. Inserting EEP into OEM is a proven methodology to assist concerned NOCs in ensuring the effectiveness of EEP implementation. It is evident from the case study that the methodology to embed EEP as one of OEM critical processes is successful in engaging strong commitment on energy efficiency through excellent OEM platform for concerned NOCs. Number of benefits and the opportunities for improvement will be captured during the actual deployment of EEP. One of major benefits is to ease the adaptation of a comprehensive EEP and ultimately drive for steady incremental improvements of energy performance. Furthermore, this concept will easily integrate into the companies' culture as many steps of EEP are quite similar to SMS, EMS or data protection management system. Subsequently, it will improve implementation pace as the need for major introductory efforts can be minimized.

\section{Acknowledgements}

The authors would express their sincere gratitude to one of anonymous National Oil Company for providing venue for case study.

\section{References}

[1] IPIECA1 (2013). Saving Energy in the oil and gas industry. The global oil and gas association for environment and social issues Climate Change. London, UK.

[2] The World Bank (2015). World Development Indicators: Electricity production, sources and access. http:// http://wdi.worldbank.org/table/3.7.

[3] Cottiers T., and Delimatris P. (2011). The Prospects of International Trade Regulation. From Fragmentation to Coherences. (1st ed.). UK. Cambridge University Press.

[4] Weynand, J. (2016). Performance excellence culture improves processes, giving lasting results. Hydrocarbon Processing. $\quad$ November 2016. Page 21.

[5] Raed, A. (2017). Industry transformation takes many forms. Journal of petroleum Technology. January 2017. Page 14.

[6] IPIECA2 (2013). Guidelines for implementing ISO50001 Energy Management System in Oil and Gas Industry. London, UK. 
Hashim K. M, Ng D. K. S \& Mimi H. Hassim /JEST-Journal of Energy and Safety Technology. vol. 1, no.2 (2018): 51 - 59

[7] ISO50001 (2011). Energy management systems - Requirements with guidance for use. Switzerland.

[8] DNV.GL (2015). Saving Energy Today for brighter tomorrow. View Point Report. May 2015. Norway.

[9] Dipaola, A. (2017). Saudis Kick Off \$50 Billion Renewable Energy Plan to Cut Oil Use. Bloomberg, (20 Feb 2017).

[10] Kaplan, R. and Norton, D. (2001). Scorecard companies thrive in the new business environment. The Strategy-Focused Organization. How balance. (1st Ed). USA. Harvard Business School Press.

[11] Arab Forum (2013). Environment and Development Executive Report Summary Recommendations. Arab Environment 6 Sustainable Energy Prospect, Challenges, Opportunities. Beirut, Lebanon. Page 1 and 9.

[12] Youssef, Y. and Abu-ebid, M. (2012). Energy Efficiency Initiatives for Saudi Arabia on supply and demand sides. Energy Research Institute, King Abdul Aziz City for Science and Technology, Riyadh. InTech, DOI: 10.5772/38660.

[13] Lahn, G., Stevens P. and Preston F. (2013). Saving Oil and Gas in the Gulf. A Chatham House Report. Page 41.

[14] ANSI/MSE 50021 (2013). American National Standards Institute (ANSI) for Superior Energy Performance. Washington DC, USA.

[15] Oh, S. P. (2015). Five keys to a total quality environment. Ingenieur. Volume 62. Apr-Jun 2014 2017, Page 43.

[16] Pyzdek, T. and Keller, P. (2013). The handbook for quality management. Complete Guide to Operational Excellence. (2nd Ed.). USA. McGraw Hill.

[17] Moubray, J. (1997). Reliability Centered Maintenance. (2nd Ed). USA. Industrial Press Inc.

[18] Agustiady, K.T. and Cudney, A.E. (2015). Total Productive Maintenance. Strategies and Implementation guide. USA. CRC Press.

[19] Bloch, H. P. (2017). Reliability and the EPC contractor. Hydrocarbon Processing. January 2017. Page 13.

[20] Hadhazy, M. (2018). How Big Data is Revolutionizing Six Sigma Application in Manufacturing. Surviving in the Age of Disruption. Supply Chain Brain. Vol 22, No. 1 February 2018, Page 35.

[21] Estes, J.M (2009). Smart Green. How to implement sustainable business practices in any industry - and make money. (1st Ed). USA. J. Wiley \& Sons, Inc.

[22] EFQM. (2012). Share what Works. An Overview of the EFQM Excellence Model. European Foundation for Quality Management. Brussels, Belgium.

[23] Mullins, L.J. (2005). Management and Organizational Behavior. (7th Ed.). UK. Prentice Hall.

[24] Energy Star (2016). Guidelines for Energy Management. United States Environment Protection Agency. USA.

[25] DuPont1 (2015). Delivering Operational Excellence to the Global Market. A DuPont Integrated Systems Approach. Du Pont Nemours and Company. USA.

[26] Chevron (2010). Operational Excellence Management System. An Overview of the OEMS. Chevron. USA

[27] Arabiya News (2015, Jan 15). Cheap oil: China's opportunities and risks. 